\title{
Evaluation of changes in blood pressure in patients submitted to dental surgical procedures
}

Avaliação das alterações na pressão arterial em pacientes submetidos a procedimentos cirúrgicos odontológicos Evaluación de alteraciones en la presión arterial en pacientes submetidos a procedimientos quirúrgicos odontológicos Poliana Keller de ANDRADE ${ }^{1}$ Rayra Batista BALESTRASSI ${ }^{1}$

Ricardo Henrique Nunes PRANDO ${ }^{1}$

Jefferson David Melo de MATOS $^{2}$

Leonardo Jiro Nomura NAKANO ${ }^{2}$

Pedro Henrique Condé Oliveira PRADO

Guilherme da Rocha Scalzer LOPES ${ }^{2}$ Marco Antonio BOTTINO ${ }^{3}$

John Eversong Lucena de VASCONCELOS ${ }^{4}$ Valdir Cabral ANDRADE ${ }^{5}$

Erick Gomes PEREZ

'Graduated in Dentistry, Faculdade São Francisco de Assis ESFA, Santa Teresa - ES, Brazil

${ }^{2}$ Post Graduate Student - Ph.D Program, Department of Dental Materials and Prosthodontics, São Paulo State University (Unesp), Institute of Science and Technology, São José dos Campos - SP. Brazil

${ }^{3}$ Full Professor of Postgraduate Program in Restorative Dentistry, Department of Dental Materials and Prosthodontics, São Paulo State University (Unesp), Institute of Science and Technology, São José dos Campos - SP, Brazil

${ }^{4}$ Professor of Implantology and Prosthodontics, Department of Dentistry, College of Dentistry CECAPE, Juazeiro do Norte - CE, Brazil

${ }^{5}$ Professor Adjunct, Department of Dentistry and Maxillofacial Surgery, Universidade Federal de Juiz de Fora UFJF, Governador Valadares - MG, Brazil

${ }^{6}$ Professor of Oral and Maxillofacial Surgery, Department of Dentistry, Faculdade São Francisco de Assis ESFA, Santa Teresa - ES, Brazil

\section{Abstract}

The present study aimed to evaluate the occurrence of significant changes in systemic blood pressure (SBP) during surgicaldental procedures. A prospective study was performed with a sample of 135 randomly selected individuals who underwent surgical procedures at the Bucomaxillofacial Surgery Clinic of the Dentistry School of the ESFA (ES) between the second half of 2017 and April 2018. After consent, sociodemographic, lifestyle data, weight and height were obtained through a questionnaire, weighing and measurement, respectively. BP measurements were performed at three moments: preoperative (BP1), intraoperative (BP2) and postoperative (BP3) using a mercury column sphygmomanometer and stethoscope. Values <120/80 $\mathrm{mmHg}$ were used as normal values. When BP1 and BP2 were compared, $63.0 \%$ remained within normal values and $22.2 \%$ reached the stage of hypertension. In the comparison of BP1 and BP3, $66.7 \%$ remained normal, and only $7.4 \%$ reached the stage of hypertension. When BP2 and BP3 were compared, 53.6\% remained within the normality stage and $12.2 \%$ reached the stage of hypertension. It was concluded that there were variations in blood pressure, being the largest variation found in BP2, and can be attributed to the stress caused by the surgical act, since no statistically significant connections were found between the changes in blood pressure and the anesthetics used in the research.

Descriptors: Surgery, Oral; Hypertension; Anxiety; Anesthetics.

\section{Resumo}

O presente estudo tem como objetivo avaliar a ocorrência de alterações significativas na pressão arterial sistêmica (PAS) durante procedimentos cirúrgicos-odontológicos. Estudo prospectivo com amostra correspondente a 135 indivíduos selecionados aleatoriamente, que foram submetidos a procedimentos cirúrgicos na clínica de Cirurgia Bucomaxilofacial do Curso de Odontologia da ESFA (ES) entre o segundo semestre de 2017 e abril de 2018. Após o consentimento, os dados sociodemográficos e de estilo de vida, peso e altura foram obtidos por meio de um questionário, pesagem e medição, respectivamente. Foram realizadas aferições da PA em três momentos: pré-operatório (PA1), transoperatório (PA2) e pósoperatório (PA3) utilizando esfigmomanômetro de coluna de mercúrio e estetoscópio. Utilizou-se como padrão de normalidade valores (<120/80 mmHg). Quando comparada a PA1 com a PA2, 63,0\% se mantiveram dentro dos valores de normalidade e 22,2\% atingiram o estágio de hipertensão. Na comparação da PA1 com a PA3, 66,7\% mantiveram estágio de normalidade e apenas 7,4\% chegaram ao estágio de hipertensão. Quando comparada a PA2 com a PA3, 53,6\% mantiveram dentro do estágio de normalidade e $12,2 \%$ atingiram o estágio de hipertensão. Conclui-se que ocorreram variações na pressão arterial, sendo a maior variação encontrada na PA2, podendo ser atribuída ao estresse causado pelo ato cirúrgico, visto que, não foram encontradas relações estatisticamente significantes nos cruzamentos entre as alterações na pressão arterial com os anestésicos utilizados na pesquisa.

Descritores: Cirurgia Bucal; Hipertensão; Ansiedade; Anestésicos.

\section{Resumen}

El presente estudio tiene como objetivo evaluar la ocurrencia de cambios significativos en la presión arterial sistémica (PAS) durante procedimientos quirúrgicos-odontológicos. Estudio prospectivo con muestra correspondiente a 135 individuos seleccionados aleatoriamente, que fueron sometidos a procedimientos quirúrgicos en la clínica de Cirugía Bucomaxilofacial del Curso de Odontología de la ESFA (ES) entre el segundo semestre de 2017 y abril de 2018. Después del consentimiento, los datos sociodemográficos y de estilo de vida, peso y altura fueron obtenidos por medio de un cuestionario, pesaje y medición, respectivamente. Se realizaron mediciones de la PA en tres momentos: preoperatorio (PA1), transoperatorio (PA2) y postoperatorio (PA3) utilizando esfigmomanómetro de columna de mercurio y estetoscopio. Se utilizó como patrón de normalidad valores $(<120 / 80 \mathrm{mmHg}$ ). Cuando se comparó la PA1 con la PA2, el 63,0\% se mantuvo dentro de los valores de normalidad y el 22,2\% alcanzó la etapa de hipertensión. En la comparación de la PA1 con la PA3, el 66,7\% mantuvieron una etapa de normalidad y sólo el 7,4\% llegó a la etapa de hipertensión. Cuando se comparó la PA2 con la PA3, el 53,6\% mantuvo dentro de la etapa de normalidad y el 12,2\% alcanzó la etapa de hipertensión. Se concluye que ocurrieron variaciones en la presión arterial, siendo la mayor variación encontrada en la PA2, pudiendo ser atribuida al estrés causado por el acto quirúrgico, ya que no se encontraron relaciones estadísticamente significativas en los cruces entre los cambios en la presión arterial con los anestésicos utilizados en la intervención búsqueda.

Descriptores: Cirugía Bucal; Hipertensión; Ansiedad; Anestésicos.

INTRODUCTION

During clinical practice, the dental surgeon routinely treats systemically compromised patients. Among them are the 
hypertensive patients who need a differentiated attention due to several external factors that can influence their systemic condition ${ }^{1}$.

Due to the high prevalence of Systemic Arterial Hypertension (SAH), which affects 30\% of the Brazilian population, it is estimated that by 2025 this disease can affect 1.6 billion people worldwide ${ }^{2}$.

Associated with SAH there are some risk factors such as smoking, alcoholism, sedentary lifestyle, age, gender, overweight and family history of hypertension, which in turn accompany the absence of symptoms for the hypertension leading to a late diagnosis, which proves to be essential to assessment of blood pressure (BP) by all health professionals ${ }^{3}$.

In order to obtain a control of the $\mathrm{SAH}$ that affects a large part of the population, the measurement of the blood pressures is performed using a manual sphygmomanometer, the most used among professionals. This step is indispensable for the best diagnosis ${ }^{4}$.

The evaluation of the BP change must be done in hand-held devices, since studies have shown that the automated gauging does not reach the level of accuracy of a manual device, making the manual blood pressure device a reference standard for its accuracy ${ }^{5-7}$.

Concerning the alteration of BP, local anesthetics present great relevance; its use in conjunction with vasoconstrictors is widely diffused in dentistry because it promotes improvement in pain control during dental procedures. However, some vasoconstrictors have the potential to increase BP values, leading to hypertensive spikes during dental procedures $^{8}$.

In addition to the aforementioned factors, the anxiety experienced by many patients must be taken into attention, since it is one of the most frequent diseases worldwide, being the same, a risk factor for cardiovascular diseases ${ }^{9}$.

The objective of the present study was to evaluate the occurrence of significant changes in systemic arterial pressure of patients submitted to dental surgical procedures at the Bucomaxillofacial Surgery Clinic of the Escola Superior São Francisco de Assis - ESFA, Santa Teresa-ES, Dentistry school.

MATERIAL AND METHOD

For the research instrument, patients were randomly selected, without age restriction and gender/ethnicity predilection who attended the Bucomaxillofacial Surgery Clinic of the Escola Superior São Francisco de Assis ESFA, Santa Teresa-ES, in the period between the second half of 2017 and April 2018 to perform surgical dental procedures. After the patient agreement to participate in the research, he/she signed a free and informed consent form (Appendix A) authorizing the research. The patients were submitted to anamnesis (Appendix $B$ ), in which questions addressed the detection of risk factors related to Systemic Arterial Hypertension. Sociodemographic and lifestyle data were addressed. For the calculation of the Body Mass Index (BMI), the weight in kilograms was recorded by means of a digital scale and the height was measured with the aid of a tape measure, classified according to the Brazilian Association for the Study of Obesity - ABESO (Annex B). The BP measurements were performed after anamnesis by the same evaluator using the palpatory and auscultatory method using a mercury column apparatus and stethoscope, and a periodic preventive calibration was made for the accuracy of BP measurement.

Three BP measurements were performed before the surgical procedure (BP1), 5 minutes after infiltration of the local anesthetic (BP2) and 5 minutes after suture (BP3). Systolic pressure was determined at the time of appearance of the first sound (korotkoff phase I), which intensified with increasing deflation velocity. The diastolic pressure was determined in the disappearance of the sound (phase $\mathrm{V}$ of Korotkoff). Approximately $20 \mathrm{mmHg}$ was heard at $30 \mathrm{mmHg}$ below the last sound to confirm its disappearance and then rapid and complete deflation proceeded. All data collected were recorded, tabulated and submitted to statistical analysis.

- Type of Study and Research Design

This is a prospective research and a comparison study of data obtained through clinical research performed at the Bucomaxillofacial Surgery Clinic of the Escola Superior São Francisco de Assis - ESFA, Santa Teresa-ES.

\section{- Research and Sample Universe}

The research universe was all the patients who attended the dental clinic of the ESFA to perform the surgical procedure. The sample comprised 135 (n) patients who underwent dental surgical procedures.

- Inclusion and Exclusion Criteria

Patients submitted to dental surgical procedures at the clinic of oral and maxillofacial surgery of the ESFA between the second half of 2017 and April 2018 were included in the study. Pregnant patients and patients who presented initial blood pressure above $160 / 100 \mathrm{mmHg}$, due to the impossibility of performing the procedure, following the clinical protocol of the institution, were excluded. 


\section{- Data analysis}

For cross-checking between categorical variables, the statistical technique used for analysis was cross-tables with chi-square test. A cross-table shows the number of cases in each category, defined by two or more groups of categorical variables. The chi-square test tests the hypothesis that the variables in a cross-table are independent and there is no relation between them. When we have a significant $p$ value $(<0.050)$ we reject this hypothesis, that is, there is some relation between these variables.

The chi-square test is not performed when there are cells with expected results of less than five for the null hypothesis, in which situation Fisher's Exact test (for $2 \times 2$ tables) or the maximum likelihood ratio will be used if the variable more than two categories. BP1 was used as a parameter among the variables due to the lower interference of external factors. The value used as a parameter of normality for blood pressure classification was: $<120 / 80 \mathrm{mmHg}$.

\section{- Ethical aspects}

This study was conducted after approval of the Research Ethics Committee - Hospital Meridional S/A (ANNEX A) under the number of CAAE: 79238017.9.0000.5070. Patient identities were preserved at all stages of the study.

All volunteers received a copy of the Free and Informed Consent Form in accordance with the Directives and Norms Regulating the National Health Council (Resolution 466/2012 CNS), and for those under 18, the term was signed by their parents or legal guardians.

\section{RESULTS}

The results of the present study are presented in Tables 1, 2, 3, 4, 5 and 6. When analyzing the age range of the sample studied those individuals with 50 years of age or older represented the highest percentage for stage II hypertension status (38.9\%), when compared to the other age groups. Cheng et al. ${ }^{10}$ report that in their sample, participants over 60 years of age $(27.8 \%)$ had elevated BP. Other studies, such as: Zhang et al. ${ }^{11}$; Xing et al. ${ }^{12}$; Shang et al. ${ }^{13}$; Zhang et al. ${ }^{14}$; Thomas et al. ${ }^{15}$, agree that hypertension is interrelated with increasing age.

Regarding smoking habits, of the interviewed patients, $14.8 \%$ answered that they were smokers and $36.1 \%$ of them reached the stage of hypertension, which is corroborated by a study by Ahmad Jamalizadeh et al. ${ }^{16}$ who report a prevalence of smoking of $11.2 \%$. Torlasco et al. ${ }^{17}$, argue that smoking was the main cause of hypertension in the population. Raposeiras-Roubín et al. ${ }^{18}$ affirm that the constant use of tobacco has the potential to raise blood pressure and cardiovascular complications can still occur. Zingg et al. ${ }^{19}$, Cymerys et al. ${ }^{20}$, Yanbaeva et al. ${ }^{21}$, Burke et al. $^{22}$, Shen et al. ${ }^{23}$, Madika e Mounier-Vehier ${ }^{24}$, Tan et al. $^{25}$ in epidemiological and genetic studies where they evaluated the role of smoking and the possible interaction of genes and the environmental factor in the initiation and development of cardiovascular diseases such as hypertension, revealed that hypertension can be induced by smoking.

Table 1. Characterization of the sample in absolute and percentage numbers

\begin{tabular}{|c|c|c|}
\hline Variables & $\mathbf{n}$ & $\%$ \\
\hline \multicolumn{3}{|l|}{ Sex } \\
\hline Male & 53 & 39,3 \\
\hline Female & 82 & 60,7 \\
\hline \multicolumn{3}{|l|}{ Age group } \\
\hline 14 to 29 years & 66 & 48,9 \\
\hline 30 to 39 years & 27 & 20,0 \\
\hline 40 to 49 years & 19 & 14,1 \\
\hline 50 years or beyond & 23 & 17,0 \\
\hline \multicolumn{3}{|l|}{ Race / Color } \\
\hline Leucoderma & 85 & 63,0 \\
\hline Feoderma & 4 & 3,0 \\
\hline Melanoderma & 45 & 33,3 \\
\hline Xanthoderma & 1 & 0,7 \\
\hline \multicolumn{3}{|l|}{ BMI } \\
\hline Normal & 60 & 44,4 \\
\hline Overweight & 47 & 34,8 \\
\hline Obesity & 28 & 20,7 \\
\hline \multicolumn{3}{|l|}{ Sedentary } \\
\hline Yes & 121 & 89,6 \\
\hline No & 14 & 10,4 \\
\hline \multicolumn{3}{|l|}{ Addiction } \\
\hline Yes & 44 & 32,6 \\
\hline No & 91 & 67,4 \\
\hline \multicolumn{3}{|l|}{ Alcoholism } \\
\hline Yes & 30 & 22,2 \\
\hline No & 105 & 77,8 \\
\hline \multicolumn{3}{|l|}{ Tabagism } \\
\hline Yes & 20 & 14,8 \\
\hline No & 115 & 85,2 \\
\hline \multicolumn{3}{|l|}{ Family history } \\
\hline Yes & 40 & 29,6 \\
\hline No & 95 & 70,4 \\
\hline \multicolumn{3}{|l|}{ Diabetes } \\
\hline Yes & 7 & 5,2 \\
\hline No & 128 & 94,8 \\
\hline \multicolumn{3}{|l|}{ Cardiovascular diseases } \\
\hline Yes & 3 & 2,2 \\
\hline No & 132 & 97,8 \\
\hline Anesthetics & & \\
\hline Yes & 121 & 89,6 \\
\hline No & 14 & 10,4 \\
\hline Clinical status 1 & & \\
\hline Normal & 27 & 20,0 \\
\hline High & 45 & 33,3 \\
\hline Hypertension I & 27 & 20,0 \\
\hline Hypertension II & 36 & 26,7 \\
\hline Clinical status 2 & & \\
\hline Normal & 27 & 20,0 \\
\hline High & 31 & 23,0 \\
\hline Hypertension I & 37 & 27,4 \\
\hline Hypertension II & 40 & 29,6 \\
\hline Clinical status 3 & & \\
\hline Normal & 28 & 20,7 \\
\hline High & 40 & 29,6 \\
\hline Hypertension I & 39 & 28,9 \\
\hline Hypertension II & 28 & 20,7 \\
\hline BP Alteration 1-2 & & \\
\hline Continued Normal BP & 17 & 12,6 \\
\hline Hypertension continued at the same stage & 56 & 41,5 \\
\hline Improved BP & 25 & 18,5 \\
\hline Worsened BP & 37 & 27,4 \\
\hline BP Alteration 2-3 & & \\
\hline Continued Normal BP & 15 & 11,1 \\
\hline Hypertension continued at the same stage & 50 & 37,0 \\
\hline Improved BP & 41 & 30,4 \\
\hline Worsened BP & 29 & 21,5 \\
\hline BP Alteration 1-3 & & \\
\hline Continued Normal BP & 18 & 13,3 \\
\hline Hypertension continued at the same stage & 57 & 42,2 \\
\hline Improved BP & 28 & 20,7 \\
\hline Worsened BP & 32 & 23,7 \\
\hline Total & 135 & 100,0 \\
\hline
\end{tabular}


About $89.6 \%$ of the patients were sedentary and $97.25 \%$ of the patients with hypertension reached the stage II hypertension, being these sedentary. Gorostegi-Anduaga et al. $^{26}$ affirm that the population class with physical inactivity along with the negative eating habits presents a strong influence and risk factor for the increase of the blood pressure. CristiMontero et al. ${ }^{27}$; Knaeps et al. ${ }^{28}$; Sacilotto et al. ${ }^{29}$; Masala et al. ${ }^{30}$; Wang et al. $^{31}$; Beyer et al. ${ }^{32}$; Ferrario et al. ${ }^{33}$, reported that the population that is more likely to be physically active and healthy may have improvements in hypertension.

Table 2. Results of crosses between variables with BP1

\begin{tabular}{|c|c|c|c|c|c|c|c|c|c|}
\hline \multirow[t]{2}{*}{ Variables } & \multicolumn{2}{|c|}{ Normal } & \multicolumn{2}{|c|}{ High } & \multicolumn{2}{|c|}{$\begin{array}{c}\text { Hypertension } \\
\text { I }\end{array}$} & \multicolumn{2}{|c|}{$\begin{array}{c}\text { Hypertension } \\
\text { II }\end{array}$} & \multirow[t]{2}{*}{ p-value } \\
\hline & $\mathrm{n}$ & $\%$ & $\mathrm{n}$ & $\%$ & $\mathrm{n}$ & $\%$ & $\mathrm{n}$ & $\%$ & \\
\hline \multicolumn{9}{|l|}{ Sex } & \multirow{3}{*}{0,435} \\
\hline Male & 7 & 25,9 & 18 & 40,0 & 12 & 44,4 & 16 & 44,4 & \\
\hline Female & 20 & 74,1 & 27 & 60,0 & 15 & 55,6 & 20 & 55,6 & \\
\hline \multicolumn{10}{|l|}{ Age group } \\
\hline 14 to 29 years & 15 & 55,6 & 26 & 57,8 & 13 & 48,1 & 12 & 33,3 & \multirow{4}{*}{$0,036^{* *}$} \\
\hline 30 to 39 years & 4 & 14,8 & 10 & 22,2 & 8 & 29,6 & 5 & 13,9 & \\
\hline 40 to 49 years & 5 & 18,5 & 5 & 11,1 & 4 & 14,8 & 5 & 13,9 & \\
\hline 50 years or more & 3 & 11,1 & 4 & 8,9 & 2 & 7,4 & 14 & 38,9 & \\
\hline \multicolumn{10}{|l|}{ Etnia } \\
\hline $\begin{array}{l}\text { Leucoderma/ } \\
\text { Xanthoderma }\end{array}$ & 15 & 55,6 & 30 & 66,7 & 14 & 51,9 & 27 & 75,0 & \multirow[b]{2}{*}{0,206} \\
\hline $\begin{array}{l}\text { Feoderma/ } \\
\text { Melanoderma }\end{array}$ & 12 & 44,4 & 15 & 33,3 & 13 & 48,1 & 9 & 25,0 & \\
\hline \multicolumn{10}{|l|}{ BMI } \\
\hline Normal & 14 & 51,9 & 24 & 53,3 & 11 & 40,7 & 11 & 30,6 & \multirow{3}{*}{0,025} \\
\hline Overweight & 5 & 18,5 & 15 & 33,3 & 14 & 51,9 & 13 & 36,1 & \\
\hline Obesity & 8 & 29,6 & 6 & 13,3 & 2 & 7,4 & 12 & 33,3 & \\
\hline \multicolumn{10}{|l|}{ Sedentary } \\
\hline Yes & 24 & 88,9 & 39 & 86,7 & 23 & 85,2 & 35 & 97,2 & \multirow{2}{*}{$0,264^{* * *}$} \\
\hline No & 3 & 11,1 & 6 & 13,3 & 4 & 14,8 & 1 & 2,8 & \\
\hline \multicolumn{10}{|l|}{ Addiction } \\
\hline Yes & 6 & 22,2 & 16 & 35,6 & 7 & 25,9 & 15 & 41,7 & \multirow{2}{*}{0,334} \\
\hline No & 21 & 77,8 & 29 & 64,4 & 20 & 74,1 & 21 & 58,3 & \\
\hline \multicolumn{10}{|l|}{ Alcoholism } \\
\hline Yes & 5 & 18,5 & 12 & 26,7 & 5 & 18,5 & 8 & 22,2 & \multirow{2}{*}{0,815} \\
\hline No & 22 & 81,5 & 33 & 73,3 & 22 & 81,5 & 28 & 77,8 & \\
\hline \multicolumn{10}{|l|}{ Tabagism } \\
\hline Yes & 2 & 7,4 & 6 & 13,3 & 3 & 11,1 & 9 & 25,0 & \multirow{2}{*}{$0,227^{* *}$} \\
\hline No & 25 & 92,6 & 39 & 86,7 & 24 & 88,9 & 27 & 75,0 & \\
\hline \multicolumn{10}{|l|}{ Family History } \\
\hline Yes & 9 & 33,3 & 11 & 24,4 & 11 & 40,7 & 9 & 25,0 & \\
\hline No & 18 & 66,7 & 34 & 75,6 & 16 & 59,3 & 27 & 75,0 & 0,430 \\
\hline Diabetes & & & & & & & & & \\
\hline Yes & 1 & 3,7 & - & - & 2 & 7,4 & 4 & 11,1 & م $068 * *$ \\
\hline No & 26 & 96,3 & 45 & 100,0 & 25 & 92,6 & 32 & 88,9 & 0,068 \\
\hline $\begin{array}{l}\text { Cardiovascular } \\
\text { Diseases }\end{array}$ & & & & & & & & & \\
\hline Yes & - & & - & - & - & - & 3 & 8,3 & **** \\
\hline No & 27 & 100,0 & 45 & 100,0 & 27 & 100,0 & 33 & 91,7 & \\
\hline Anesthetics & & & & & & & & & \\
\hline Epinephrine & 24 & 88,9 & 43 & 95,6 & 26 & 96,3 & 28 & 77,8 & \\
\hline Felypressin & 3 & 11,1 & 2 & 4,4 & 1 & 3,7 & 8 & 22,2 & $0,045^{\prime \prime}$ \\
\hline Total & 27 & $\mathbf{o o}, \mathbf{o}$ & 45 & 100,0 & 27 & 100,0 & 36 & 100,0 & \\
\hline
\end{tabular}

In the Hypertension I and II groups there is a lower percentage of normal BMl when compared to the Normal and High BP groups. In the Hypertension I group there is a higher percentage of overweight individuals. These results corroborate with Jung et al. $^{34}$ and Fonseca $^{35}$ where they reported that the prevalence of systemic arterial hypertension is 3 times higher in overweight individuals. Similarly, Stenehjem, Hjerkind e Nilsen ${ }^{36}$ showed that a large part of their sample had body mass index associated with hypertension in both sexes ( $P$ $<0.001$ ). Buscot et al. ${ }^{37}$ using BMI methods to identify increased cardiovascular risk in individuals who were overweight and obese by identifying an increase in cardiovascular risk, thus, participants who had high BMl had a greater risk of developing hypertension. Someya et al. ${ }^{38}$; Wu et al. $^{39}$ and Colangelo et al. ${ }^{40}$ confirms that the risk of developing hypertension grows along with increased obesity and BMI.

Table 3. Results of crosses between BP1 and BP2

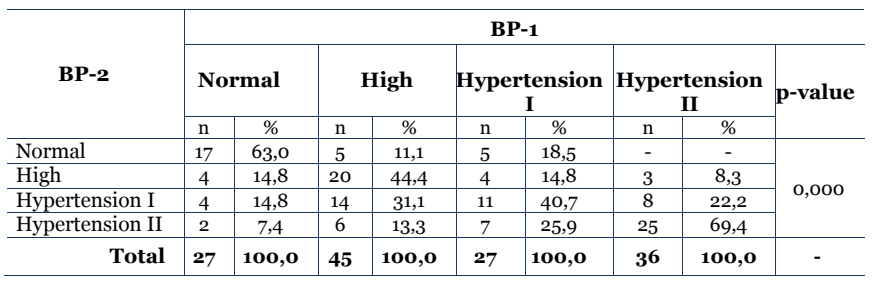

Considering that the $p$-value was $<0.050$, a statistically significant relationship was observed in the cross-referencing of BP1 and BP2 in BP1 patients with normal BP, $63.0 \%$ continued with normal BP in BP2, $14.8 \%$ progressed to Elevated, $14.8 \%$ progressed to Hypertension I and 7.4\% to Hypertension II.

When BP 2 was evaluated, no individual achieved normal BP. On the other hand, individuals who were in stage I in BP1, 18.5\% improved to reach the normal BP level. These results corroborate with Rodrigues et al. ${ }^{41}$ who found similar results when analyzing hypertensive and normotensive individuals at three moments, where, respectively, $80 \%$ and $97.7 \%$ of subjects maintained blood pressure within the normal range. Barbosa e Assis ${ }^{42}$ in a study that assessed blood pressure during exodontia reported an increase in blood pressure after anesthesia, as well as Tolentino et al. ${ }^{43}$ in a similar study $11.5 \%$ of subjects had increased blood pressure during the clinical procedure. Ferraz et al. ${ }^{44}$ reported that the highest values of systolic arterial hypertension were identified prior to anesthesia, which may be suggestive of a strong influence of anxiety, since the same study shows that the highest values of diastolic arterial hypertension were observed in the at the moment of the extraction, which is explained by the influence of the surgical technique that is sensitive to the operator.

Table 4. Results of crosses between BP1 and BP3

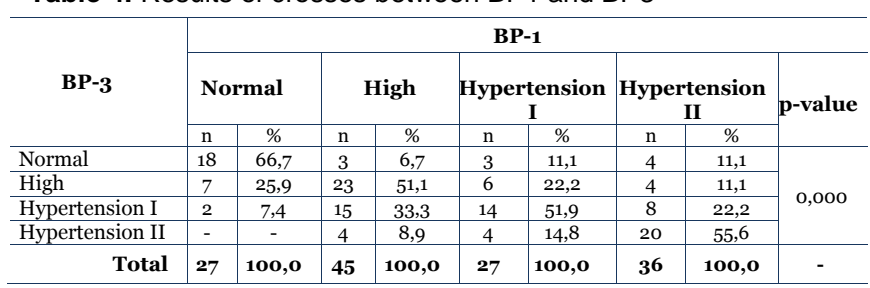

The results of the cross-over between BP1 and BP3 were statistically significant because they obtained a $p$-value $=0.000$. Of the patients with BP classified as normal in BP1, 
$66.7 \%$ continued with normal BP in BP 3, 25.9\% evolved to elevated, $7.4 \%$ progressed to Hypertension I and none to Hypertension II.

When stage II was evaluated, $55.6 \%$ remained at the same stage of $\mathrm{BP}$ and $11.1 \%$ of subjects achieved BP. On the other hand, individuals who were in stage I in BP1, $11.1 \%$ improved to normal BP level and $51.9 \%$ remained in the same stage of $\mathrm{BP}$.

The results found corroborate with Rodrigues et al. ${ }^{41}$ who reported that $82 \%$ of normotensive individuals remained within the limits of normality and among hypertensive individuals $40 \%$ remained within normal limits. As well as the study by Barbosa ${ }^{42}$ who described that there was similarity between the initial and final stages in the comparison between BP I and BP III and Oliveira et al. ${ }^{45}$ who reported that there was no statistical difference in pressure values when compared to the beginning and end of the dental procedure.

Table 5. Results of crosses between BP2 and BP3

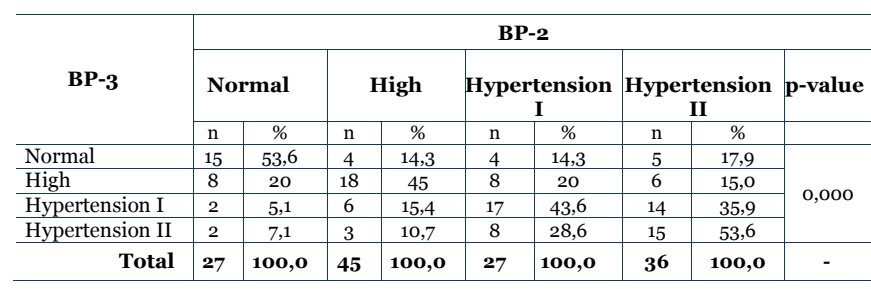

Of the patients with BP classified as normal in BP2, 53.6\% continued with normal BP in $\mathrm{BP} 3,20.0 \%$ evolved to elevated, $5.1 \%$ progressed to Hypertension I and $7.1 \%$ to Hypertension II.

When stage II was evaluated, 53.6\% remained at the same stage of $\mathrm{BP}$ and $17.9 \%$ of subjects achieved BP. On the other hand, individuals who were in stage I in BP 1, 14.3\% improved to normal BP level and $43.6 \%$ remained in the same stage of $\mathrm{BP}$.

Salim et al. $^{46}$ in a study that sought to identify arterial hypertension in patients who were to undergo dental treatment, found that $76.6 \%$ of the patients with $\mathrm{BP}$ classified as normal in BP II continued with normal BP at the moment of BP III measurement. Ganhoto et al. ${ }^{47}$ reported that the intraoperative moment presented significantly higher blood pressure elevation than in the pre and postoperative moments. This corroborates with the present study, where the intraoperative moment (BP2) was the one that presented the highest elevation of the arterial pressure and this variation of the BP after the anesthesia is associated with the previous psychological factor of the patient in relation to the anesthesia and still attributed to the stress and the pain due to non-accuracy of the anesthetic technique applied during the surgical procedure ${ }^{44,48-52}$.

Annibelli et al. ${ }^{53}$ observed that in the postoperative period the systolic blood pressure presented higher values, however, statistically there were no significant differences between the preoperative, intraoperative and postoperative moments, which can be explained by the low number of the sample that was limited to 22 individuals, whereas in the present study the sample consisted of 135 individuals.

Table 6. Results of the crosses between some variables of the study with the Groups

\begin{tabular}{|c|c|c|c|c|c|}
\hline \multirow{3}{*}{ Variables } & \multicolumn{4}{|c|}{ Anesthetics } & \multirow{3}{*}{ p-value } \\
\hline & \multicolumn{2}{|c|}{ Epinephrine } & \multicolumn{2}{|c|}{ Felypressin } & \\
\hline & $\mathbf{n}$ & $\%$ & $\mathbf{n}$ & $\%$ & \\
\hline \multicolumn{5}{|l|}{ BP Alteration 1-2 } & \multirow{5}{*}{$0,726^{* *}$} \\
\hline Continued Normal BP & 16 & 13,2 & 1 & 7,1 & \\
\hline $\begin{array}{l}\text { Hypertension continued } \\
\text { at the same stage }\end{array}$ & 51 & 42,1 & 5 & 35,7 & \\
\hline Improved BP & 21 & 17,4 & 4 & 28,6 & \\
\hline Worsened BP & 33 & 27,3 & 4 & 28,6 & \\
\hline \multicolumn{5}{|l|}{ BP Alteration 2-3 } & \multirow{5}{*}{$0,455^{* *}$} \\
\hline Continued Normal BP & 14 & 11,6 & 1 & 7,1 & \\
\hline $\begin{array}{l}\text { Hypertension continued } \\
\text { at the same stage }\end{array}$ & 42 & 34,7 & 8 & 57,1 & \\
\hline Improved BP & 38 & 31,4 & 3 & 21,4 & \\
\hline Worsened BP & 27 & 22,3 & 2 & 14,3 & \\
\hline \multicolumn{5}{|l|}{ BP Alteration 1-3 } & \multirow{5}{*}{$0,890^{* *}$} \\
\hline Continued Normal BP & 16 & 13,2 & 2 & 14,3 & \\
\hline $\begin{array}{l}\text { Hypertension continued } \\
\text { at the same stage }\end{array}$ & 52 & 43,0 & 5 & 35,7 & \\
\hline Improved BP & 24 & 19,8 & 4 & 28,6 & \\
\hline Worsened BP & 29 & 24,0 & 3 & 21,4 & \\
\hline Total & 121 & 100,0 & 14 & 100,0 & - \\
\hline
\end{tabular}

\section{DISCUSSION}

An important concern during clinical practice among dental surgeons is about the use of local anesthetics with or without vasoconstrictors, since this procedure could further increase the patient's blood pressure, which according to Silvestre et al. ${ }^{54}$ did not observe hemodynamic changes between the groups that used vasoconstrictor and those that did not use.

Regarding anesthetics, when there was an elevation in the patients blood pressure, regardless of whether they were hypertensive or not, no statistically significant relations were found between the changes in BP and anesthetics. This is corroborated by the studies of Goulart et al ${ }^{55}$; Ogunlewe et al. ${ }^{56}$; Gungormus e Buyukkurt ${ }^{57}$; where there was no significant change in blood pressure in relation to the type of anesthetic solution used.

About the use of epinephrine in hypertensive patients, Perusse, Goulet \& Turcotte $(1992)^{58}$; Carvalho et al. ${ }^{59}$, recommend that the maximum safe dose may be $22 \%$ lidocaine tubes with epinephrine 1:100,000. Niwa et al. ${ }^{60}$ and Bader et al. ${ }^{61}$ showed a small increase in BP when associated with the use of epinephrine in controlled hypertensive patients; however, authors such as Bronzo ${ }^{62}$; Perusse et 
al. ${ }^{58}$; Soares et al. ${ }^{63}$; Cáceres et al. ${ }^{64}$ recommend the use of vasoconstrictors without compromising the patient, provided that the maximum recommended dose is respected. Niwa et al. ${ }^{60}$ emphasize that the vasoconstrictor promotes adequate, long-lasting anesthesia, furthermore promotes homeostasis, leading to reduction of patient pain and release of catecholamines.

Alemany et al. ${ }^{65}$; Santos ${ }^{66}$; Rios et al. ${ }^{67}$ argue that stress attenuation associated with anxiolytics or sedation, when well indicated, produce beneficial effects in reducing the cardiovascular response associated with preoperative anxiety of the patient. Although the first technique to be used in these cases is the behavioral control of the patient mediated by the dentist, as previous explanations about how the dental procedure will be performed, improving the anxiety and allowing a better conduction of the procedure.

Authors such as Medeiros et al. ${ }^{68}$; Carvalho et al. ${ }^{59}$; Loggia et al. $^{69}$; Tanno e Marcondes ${ }^{70}$; reported the physiological action of anxiety on blood pressure change and stated that fear and anxiety directly influence the pressure measurement. The change in blood pressure can be explained by the stress caused in the outpatient setting, causing the main mediators of the stress reaction, the catecholamines released by the sympathetic nervous system and the medulla of the adrenal gland, and the glucocorticoids released by adrenal cortex, where both provide cellular events that enable adaptive changes in cells and tissues, with the role of protecting the organism and ensuring its survival. On the central nervous system, the endogenous release of adrenaline produces an excitatory effect. In response to these actions, there is an increase in blood pressure, in addition to an eventual alteration of potentiation of local anesthesia.

Oliveira et al. ${ }^{45}$ and Goulart et al. ${ }^{55}$ stated that anxiety, fear and pain were not able to significantly alter blood pressure, contrary to the authors previously cited. This can be explained by the type of procedure performed, since the study by Oliveira et al. ${ }^{45}$ deals with endodontic treatment, considered less stressful than dental extractions. Another explanation is the fact that the authors worked with a different sample in quantitative terms than the one used in this study $(n=135)$.

In the study by Goulart et al. ${ }^{55}$ a $\mathrm{n}$ of 60 was used. Other factors studied, such as sex, ethnicity, alcoholism and family history, did not show a significant $p$-value significance $(>0.050)$ when related to the state of $\mathrm{SAH}$, despite of its proven correlation in several studies, therefore, more detailed studies should be performed to better prove this relationship.

Changes in systolic and diastolic BP are observed in patients before and during clinical dental procedures. These changes may be associated with pain, stress due to fear and anxiety during the surgical procedure, and also by individual factors such as age, hypertension, previous traumatic experience in dental treatment, psychological response, poor eating habits, sedentary lifestyle, BMI and tobacco, where a large part of these patients who undergo dental procedures can observe the increase in BP throughout the clinical procedure performed.

CONCLUSION

It can be concluded from this study that there was variation of BP throughout the dental surgical procedure, the moment where there was a major alteration was after BP2 anesthesia, corroborating with the literature data. These variations can be attributed to anxiety and stress caused by the surgical act; the reduction of stress, as well as the control of anxiety and fear of a dental treatment are beneficial in the care of hypertensive patients. It is worth mentioning that the measurement of preoperative BP (BP1) and its monitoring throughout the length of the surgical procedure is of fundamental importance for the best conducts to be taken

The sedentary lifestyle was the most prevalent comorbidity among the individuals in the sample, since the hypertensive patients are asymptomatic, routine control is fundamental. When precociously diagnosed and well controlled, it makes dental procedures safer. Local anesthetics associated with vasoconstrictors, such as adrenaline and felypressin, may be used to treat patients with stage I or II controlled hypertension in dentistry. It is important to emphasize that the present study did not intend to diagnose Systemic Arterial Hypertension, since for the diagnosis another methodology should be used. Therefore, we suggest other studies that may diagnose Systemic Arterial Hypertension.

\section{REFERENCES}

1. Lima SG, Albuquerque MF, Oliveira JR, Ayres CF, Cunha JE, Oliveira DF et al. Exaggerated blood pressure response during the exercise treadmill test as a risk factor for hypertension. Braz J Med Biol Res. 2013;46(4):368-74.

2. ACC/AHA/AAPA/ABC/ACPM/AGS/APhA/ASH/ ASPC/NMA/PCNA guideline for the prevention, detection, evaluation, and management of high 
blood pressure in adults: a report of the American College of Cardiology/American Heart Association Task Force on Clinical Practice Guidelines. J Am Coll Cardiol. 2017; 24430.

3. Silva GV, Ortega KC, Mion Jr D. Monitorização Residencial da Pressão Arterial (MRPA). Rev Bras Hipertens. 2008;15(4):215-19.

4. Zahid H, Amin A, Amin E, Waheed S, Asad A, Faheem $A$ et al. Prevalence and predictors of use of home sphygmomanometers among hypertensive patients. Cureus. 2017; 9(4):e1155.

5. Guedis AG, Sousa BDBD, Marques CF, Piedra DPS, Braga JCMS, Cardoso MLG et al. Hipertensão do avental branco e sua importância de diagnóstico. Rev Bras Hipertens. 2008;15(1):46-50.

6. Goulart JCF, Pinheiro MD, Rodrigues RV, Santos FDSAD, Martins AT, Scannavino FLF. Influence of anxiety on blood pressure and heart rate during dental treatment. Rev odonto ciênc. 2012;27(1):31-5.

7. Mirdamadi A, Etebari M. Comparison of manual versus automated blood pressure measurement in intensive care unit, coronary care unit, and emergency room. ARYA Atheroscler. 2017;13(1):29-34.

8. Abu-Mostafa N, Al-Showaikhat F, Al-Shubbar F, Al-Zawad K, Al-Zawad F. Hemodynamic changes following injection of local anesthetics with different concentrations of epinephrine during simple tooth extraction: A prospective randomized clinical trial. J Clin Exp Dent. 2015;7(4):e471-6.

9. Bajkó Z, Szekeres CC, Kovács KR, Csapó K, Molnár S, Soltész $\mathrm{P}$ et al. Anxiety, depression and autonomic nervous system dysfunction in hypertension. J Neurol Sci. 2012; 317(1-2):112-16.

10.Cheng I, Ho WE, Woo BK, Tsiang JT. Correlations between Health Insurance Status and Risk Factors for Cardiovascular Disease in the Elderly Asian American Population. Cureus. 2018;10(3):e2303.

11. Zhang ZB, Xue ZX, Chen HY, Wang TM, Li YH, Chao XF et al. [Prevalence of hypertension and risk factors in Uygur population in Kashgar area of Xinjiang Uygur Autonomous Region]. Zhonghua Liu Xing Bing Xue Za Zhi. 2017;38(6):709-14.

12. Xing CY, Tarumi $T$, Meijers RL, Turner $M$, Repshas J, Xiong L, Ding K, Vongpatanasin W, Yuan LJ, Zhang R. Arterial Pressure, Heart Rate, and Cerebral Hemodynamics Across the Adult Life Span. Hypertension. 2017;69(4):712-20.

13. Shang S, Li P, Deng M, Jiang Y, Chen C, Qu Q. The Age-Dependent Relationship between Blood Pressure and Cognitive Impairment: A Cross-Sectional Study in a Rural Area of Xi'an, China. PLoS One. 2016;11(7):e0159485.

14.Zhang YJ, Wu SL, Li HY, Zhao QH, Ning $\mathrm{CH}$,
Zhang RY et al. [Comparison of arterial stiffness in non-hypertensive and hypertensive population of various age groups]. Zhonghua Xin Xue Guan Bing Za Zhi. 2018;46(1):56-63

15. Thomas F, Empana JP, Charles MA, Boutouyrie $P$, Jouven $X$, Pannier $B$ et al. Silhouettes at different age of life: Retrospective appreciation of corpulence and his impact on prevalence of hypertension at 60years. Ann Cardiol Angeiol (Paris). 2017;66(3):171-75.

16. Jamalizadeh A, Kamiab Z, Esmaeili Nadimi A, Nejadghaderi M, Saeidi A, Porkarami A. Prevalence of smoking and high blood pressure, two major risk factors for noncommunicable diseases: the SuRF NCD (surveillance of risk factors of noncommunicable disease) report 2012. J Cardiovasc Thorac Res. 2016;8(4):183-87.

17. Torlasco C, Faini A, Makil E, Ferri C, Borghi C, Veglio $\mathrm{F}$ et al. Council of the Italian Society of Hypertension. Cardiovascular risk and hypertension control in Italy. Data from the 2015 World Hypertension Day. Int J Cardiol. 2017;243:529-32.

18. Raposeiras-Roubín S, Abu-Assi E, IñiguezRomo A. Tobacco, illicit drugs use and risk of cardiovascular disease in patients living with HIV. Curr Opin HIV AIDS. 2017;12(6):523-27.

19.Zingg S, Collet TH, Locatelli I, Nanchen D, Depairon M, Bovet $P$ et al. Associations between cardiovascular risk factors, inflammation, and progression of carotid atherosclerosis among smokers. Nicotine Tob Res. 2016;18(6):1533-8.

20.Cymerys, M., Bogdański, P., Pupek-Musialik, D., Jabłecka, A., Łącki, J., Korczowska, I., \& Dytfeld, J. Influence of hypertension, obesity and nicotine abuse on quantitative and qualitative changes in acute-phase proteins in patients with essential hypertension. Med Sci Monit. 2012;18(5):CR330-CR336.

21. Yanbaeva DG, Dentener MA, Creutzberg EC, Wesseling G, Wouters EF. Systemic effects of smoking. Chest. 2007;131(5):1557-66.

22. Burke GM, Genuardi M, Shappell H, D'Agostino RB Sr, Magnani JW. Temporal Associations Between Smoking and Cardiovascular Disease, 1971 to 2006 (from the Framingham Heart Study). Am J Cardiol. 2017;120(10):1787-91.

23. Shen Q, Zhu NB, Yu CQ, Guo Y, Bian Z, Tan $Y L$ et al. [Sex-specific associations between tobacco smoking and risk of cardiovascular diseases in Chinese adults]. Zhonghua Liu Xing Bing Xue Za Zhi. 2018;39(1):8-15.

24. Madika AL, Mounier-Vehier C. Tabac et pression artérielle: une relation complexe à mieux connaître. La Presse Médicale. 2017;46(7-8):697-702.

25. Tan J, Zhang X, Wang W, Yin P, Guo X, Zhou, $M$. Smoking, blood pressure, and cardiovascular disease mortality in a large 
cohort of chinese men with 15 years followup. Int J Environ Res Public Health. 2018;15(5):1026.

26. Gorostegi-Anduaga I, Corres $\mathrm{P}$, Jurio-Iriarte $\mathrm{B}$, Martínez-Aguirre A, Pérez-Asenjo J, Aispuru GR et al.. Clinical, physical, physiological, and dietary patterns of obese and sedentary adults with primary hypertension characterized by sex and cardiorespiratory fitness: EXERDIET-HTA study. Clin Exp Hypertens. 2018;40(2):141-49.

27. Cristi-Montero C, Steell L, Petermann F, Garrido-Méndez A, Díaz-Martínez X, SalasBravo $C$ et al. Joint effect of physical activity and sedentary behaviour on cardiovascular risk factors in Chilean adults. J Public Health (Oxf). 2018;40(3):485-92.

28. Knaeps S, De Baere S, Bourgois J, Mertens E, Charlier R, Lefevre J. Substituting sedentary time with light and moderate to vigorous physical activity is associated with better cardiometabolic health. J Phys Act Health. 2018;15(3):197-203.

29. Sacilotto MC, Del Grossi RT, Sirol FN, Pessotti ER, Catai MA., Sakabe DI et al. Relação da freqüência cardíaca e da potência no pico do teste ergométrico e no nível do limiar de anaerobiose de homens de meia-idade saudáveis e de hipertensos. Fisioter mov.2007;20(4):43-53.

30. Masala G, Bendinelli B, Versari D, Saieva C, Ceroti M, Santagiuliana F et al. Anthropometric and dietary determinants of blood pressure in over 7000 Mediterranean women: the European Prospective Investigation into Cancer and Nutrition-Florence cohort. J Hypertens. 2008;26(11):2112-20.

31. Wang X, Strizich G, Hua S, Sotres-Alvarez D, Buelna C, Gallo LC et al. Objectively measured sedentary time and cardiovascular risk factor control in US Hispanics/Latinos with diabetes mellitus: Results from the Hispanic Community Health Study/Study of Latinos (HCHS/SOL). J Am Heart Assoc. 2017;6(6):e004324.

32. Beyer KM, Szabo A, Hoormann K, Stolley M. Time spent outdoors, activity levels, and chronic disease among American adults. J Behav Med. 2018;41(4):494-503.

33. Ferrario MM, Roncaioli M, Veronesi G, Holtermann A, Clays E, Borchini $R$ et al. Differing associations for sport versus occupational physical activity and cardiovascular risk. Heart. 2018;104(14):1165-72.

34. Jung DH, Kim JY, Kim JK, Koh SB, Park JK, Ahn SV. Relative contribution of obesity and serum adiponectin to the development of hypertension. Diabetes Res Clin Pract. 2014; 103(1):51-6.

35. Fonseca JGM. Obesidade e outros distúrbios alimentares. São Paulo: Medsi; 2001.

36. Stenehjem JS, Hjerkind KV, Nilsen TI. Adiposity, physical activity, and risk of hypertension: prospective data from the population-based HUNT Study, Norway. J Hum Hypertens. 2018;32(4):278-86.

37. Buscot MJ, Thomson RJ, Juonala M, Sabin MA, Burgner DP, Lehtimäki T et al. Distinct child-toadult body mass index trajectories are associated with different levels of adult cardiometabolic risk. Eur Heart J. 2018 Jun 21;39(24):2263-2270.

38. Someya Y, Tamura Y, Kohmura Y, Aoki K, Kawai S, Daida H. Slightly increased BMI at young age is a risk factor for future hypertension in Japanese men. PloS One. 2018;13(1):e0191170.

39. Wu O, Leng JH, Yang FF, Yang HM, Zhang $\mathrm{H}$, Li ZF et al. A comparative research on obesity hypertension by the comparisons and associations between waist circumference, body mass index with systolic and diastolic blood pressure, and the clinical laboratory data between four special Chinese adult groups. Clin Exp Hypertens. 2018;40(1):16-21.

40. Colangelo LA, Vu TH, Szklo M, Burke GL, Sibley C, Liu K. Is the association of hypertension with cardiovascular events stronger among the lean and normal weight than among the overweight and obese? The multi-ethnic study of atherosclerosis. Hypertension. 2015;66(2):286-93.

41. Rodrigues CS, Silveira JCF, Castro SHD, Silva FSC. Avaliação da variação da pressão arterial em pacientes submetidos a tratamento odontológico. Rev odontol Univ Cid São Paulo. 2017;25(3):196-202.

42. Barbosa VA, Assis AF. Avaliação das alterações da pressão arterial sistêmica durante procedimento de exodontia [monografia]. Salvador: Curso de Residência e Especialização em Cirurgia e Traumatologia Bucomaxilofacial da Escola Bahiana de Medicina e Saúde Pública; 2016.

43. Bernardino Junior R, Tolentino AB, Ferreira GT, Silva D, Strini PJSA, Strini PJSA et al. Pressão arterial antes, durante e após atendimento em serviço de urgência odontológica. Rev Odontol Bras Central 2014;23(65):108-12.

44. Ferraz EG, Carvalho CM, Jesuíno AA, Provedel $L$, Sarmento VA. Avaliação da variação da pressão arterial durante 0 procedimento cirúrgico odontológico. Rev Odontol UNESP. 2007;36(3):223-29.

45. Oliveira PC, Zanetta-Barbosa D, Souza HJ, Batista JD, Ranali J, Costa MD et al. Avaliação do nível de ansiedade e dor de pacientes em urgências endodônticas e sua influência sobre parâmetros cardiovasculares. Cienc Odontol Bras. 2007;10(4):70-5.

46. Salim MAA, Cançado RP, Carvalho BM, Zampirolli FA, Cabral AM, Moreira TG. Identificação da hipertensão arterial sistêmica e fatores de risco em pacientes atendidos nas 
clínicas de Cirurgia Bucomaxilofacial da Faculdade de Odontologia da Faesa (ES). Rev bras odontol. 2011;68(1):39-43.

47. Ganhoto APA, Cabral ADM, Vasquez EC, Ganhoto MRA, Lima EG. Monitorização ambulatorial da pressão arterial em indivíduos submetidos à cirurgia periodontal. Rev Bras Hipertens. 2006;13(2):97-103.

48. Siviero M, Nhani VT, Prado EDFGB. Análise da ansiedade como fator preditor de dor aguda em pacientes submetidos a exodontias ambulatoriais. Rev odontol UNESP. 2008;37(4):329-36.

49. Costa RR, Silva PVR, Iwaki Filho L, Takeshita WM, Farah GJ. Avaliação da influência da expectativa e da ansiedade do paciente odontológico submetido a procedimento cirúrgico a partir de seus sinais vitais. Rev Odontol UNESP. 2012;41(1):43-7.

50. Kanegane K, Penha SS, Borsatti MA, Rocha RG. Ansiedade ao tratamento odontológico no atendimento de rotina. RGO. 2006;54(2):111-4.

51. Possobon RDF, Camillo Carrascoza K, Alves de Moraes AB, Costa Jr AL. O tratamento odontológico como gerador de ansiedade. Psicologia em estudo. 2007;12(3):609-16.

52. Lima FJ, Evangelista APA, Silva RTM, Alves PM, Lins RDAU, Godoy GP. Alterações da pressão arterial em pacientes submetidos à biópsia na cavidade oral. Arq Odontol. 2010;46(4):208-12.

53. Annibelli R, Nishimori LE, Pereira MO, Vissoci JRN, Corrêa GO, Progiante PS. Relação entre emoções, variáveis Fisiológicas e dor em pacientes de cirurgia Odontológica. BJSCR. 2014;5(3):27-32.

54. Silvestre FJ, Salvador-Martínez I, Bautista D, Silvestre-Rangil J. Clinical study of hemodynamic changes during extraction in controlled hypertensive patients. Med Oral Patol Oral Cir Bucal. 2011;16(3):e354-8.

55. Goulart JCF, Pinheiro MD, Rodrigues RV, Santos FDSAD, Martins AT, Scannavino FLF. Influence of anxiety on blood pressure and heart rate during dental treatment. Revista Odonto Ciênc. 2012;27(1):31-5.

56. Ogunlewe MO, James O, Ajuluchukwu JN, Ladeinde AL, Adeyemo WL, Gbotolorun OM. Evaluation of haemodynamic changes in hypertensive patients during tooth extraction under local anaesthesia. West Indian Med J. 2011;60(1):91-5.

57. Gungormus $M$, Buyukkurt MC. The evaluation of the changes in blood pressure and pulse rate of hypertensive patients during tooth extraction. Acta Med Austriaca. 2003;30(5):127-9.

58. Perusse R, Goulet JP,Turcotte JY. Contraindications to vasoconstrictors in dentistry: Part II. Hyperthyroidism, diabetes, sulfite sensitivity, cortico-dependent asthma, and pheochromocytoma. Oral surg oral med oral pathol. 1992;74(5):687-91.

59. Carvalho B, Fritzen EL, Parodes AG, Santos RB, Gedoz L. O emprego dos anestésicos locais em Odontologia: Revisão de Literatura. Rev Bras Odontol. 2013;70(2):178-81.

60. Niwa, H., Sugimura, M., Satoh, Y., \& Tanimoto, A. Cardiovascular response to epinephrinecontaining local anesthesia in patients with cardiovascular disease. Oral Surg Oral Med Oral Pathol Oral Radiol Endod. 2001;92(6):610-16.

61. Bader JD, Bonito AJ, Shugars DA. A systematic review of cardiovascular effects of epinephrine on hypertensive e dental patients. Oral Surg Oral Med Oral Pathol Oral Radiol Endod. 2002;93(6):647-53.

62. Bronzo ALA. Procedimentos odontológicos em pacientes hipertensos com ou sem o uso de anestésico local prilocaína associada ou não ao vasoconstritor felipressina [dissertação]. São Paulo: Faculdade de Medicina da Universidade de São Paulo); 2005.

63. Soares RG, Salles AA, Irala DLE, Limongi O. Como escolher um adequado anestésico local para as diferentes situações na clínica odontológica diária?. RSBO. 2006;3(1):35-40.

64. Cáceres MTF, Ludovice ACP, Brito FSD, Darrieux FC, Neves RS, Scanavacca MI et al. Efeito de anestésicos locais com e sem vasoconstritor em pacientes com arritmias ventriculares. Arq Bras Cardiol. 2008; 91(3):142-47.

65. Alemany-Martínez A, Valmaseda-Castellón E, Berini-Aytés L, Gay-Escoda C. Hemodynamic changes during the surgical removal of lower third molars. J Oral Maxillofac Surg. 2008; 66(3):453-61.

66. Santos DP. Controle da ansiedade odontológica: estudo comparativo entre a sedação oral com midazolam e a sedação consciente com a mistura de óxido nitroso e oxigênio em pacientes submetidos à extração de terceiros molares inferiores [dissertação]. Faculdade de odontologia de Ribeirão Preto USP; 2012.

67. Ríos Erazo M, Herrera Ronda A, Rojas Alcayaga G. Ansiedad dental: evaluación y tratamiento. Av Odontoestomatol. 2014;30(1):39-46.

68. Medeiros LDA, Ramiro FMS, Lima CAA, Souza LMDA, Fortes TMV, Groppo FC. Avaliação do grau de ansiedade dos pacientes antes de cirurgias orais menores. Rev Odontol UNESP. 2013;42(5):357-63.

69. Loggia ML, Schweinhardt P, Villemure C, Bushnell MC. Effects of psychological state on pain perception in the dental environment. $\mathrm{J}$ Can Dent Assoc. 2008;74(7):651-56.

70. Tanno AP, Marcondes FK. Estresse, ciclo reprodutivo e sensibilidade cardíaca às catecolaminas. Rev Bras Ciênc Farm. 2002;38(3):273-89. 


\section{CONFLICTS OF INTERESTS}

The authors declare no conflicts of interests.

\section{CORRESPONDING AUTHOR}

\section{Jefferson David Melo de Matos}

Department of Dental Materials and Prosthodontics,

São Paulo State University (Unesp),

Institute of Science and Technology,

São José dos Campos - SP, Brasil

Av. Eng. Francisco José Longo, 777/778, Jardim São

Dimas 12245-000 São José dos Campos - SP, Brasil

e-mail: matosjefferson19@gmail.com

Received 13/11/2019

Accepted 08/04/2020 